\title{
ON POETESSES MENTIONED IN THE MEMOIR 'RUZE RAVSHAN' BY MUHAMMAD MUZAFFAR HUSSEIN
}

\author{
Tuychiyeva Oydin Sayfullayevna \\ Teacher in Tashkent State University of Uzbek language and literature
}

Article DOI: https://doi.org/10.36713/epra4521

\begin{abstract}
The study examines the textual aspects of the lithograph of Ruzi Ravshan (رو شن روز) by Muhammad Muzaffar Husayn kept under the number №3700 at the Institute of Oriental Studies named after Abu Rayhan Beruni, Uzbekistan Sciences Academy, and information about the women whose names are mentioned in it is studied. Similarly, the image of women given in Fakhry Hiravy's first memoir dedicated to women, "Javohir ul-ajoyib", is compared to that of "Ruze Ravshan" through poetic pieces peculiar to women to compare types of fine arts. This, in turn, plays an important role in restoring the creativity of poetesses and in defining their place in socio-cultural life.
\end{abstract}

KEYWORDS: "Ruze Ravshan", "Javohir ul-ajoyib", Saida Begim, Hijabiy, Fatima Hotun, memoir, verse, divine love, pain, separation.

\section{INTRODUCTION}

Memoir as a genre has been formed since ancient times and is very common in the literature of the peoples of the East. In the words of the famous writer Khurshid Davron, memoir "serves as a unique genre of literary criticism in the creation of the history of national and interrelated literature, the study of the literary environment of a particular period, the study of individual literary figures and works." The term "tazkira" (translated as memoir) is derived from the Arabic word "zikr", which means "notebook", "to remember", "to keep in mind", "memoir". Before the Safavid period (1502-1736), the word tazkira was used in all Persian literary sources, meaning "monument", "remembrance", "memorization". Gradually, the word tazkira was used in the sense of "Shoirlar Tazkirasi" (The memoir of poets), which contains information about the origin of poets, examples of their creative work, and is still preserved in this sense today. [6: 2] Tazkira is a literary source that provides information about the biographies and works of poets, and sometimes memoir writers may also criticize the poets and their works cited in the work [6:2].

There are also memoirs in which women's names are mentioned. While the names of some female artists appear in general memoirs, some are included in special memoirs dedicated only to women. Through these memoirs, we gain a brief account of the fate of women artists and their work.

One of the oldest memoirs, Muhammad Avfiy's "Lubob ul-albob", mentions the names of two poetesses, Robiya bint-Ka'b and the daughter of Kashgari, along with men. In it, the Persian poetess Robiya's skill in ghazalism is discussed. Robiya is said to have been a ghazal writer and to have sacrificed her life as she was in love with her slave [8:1]. Robiya was from a well-off family. Since her father was the governor of Balkh and Kandahar, she had no match in reading and writing. Robiya, who had a special love for poetry, wrote poems in Persian and Dari. Robiya's brother realizes her love towards a slave through a poem she wrote, and executes her [9] In the work "Tazkirat ush-shuaro" written by Davlatshoh Samarkandy in 892, among hundreds of poets Dilorom Changi, Pari, Mahastiy, and Jahan Khotuns are mentioned as people of poetry and literature.

Dr. Ruhangiz Karochi, while studying the women in Alisher Navoi's "Majolis un-nafois", finds that the work also gives a brief account of three poetesses among 459 poets. Among these, the 


\section{EPRA International Journal of Research and Development (IJRD)

mention of Mehriy Hiratiy by Mawlana Sulaymaniy is in fact that of doctor Mawlana Hakim's wife Mehrini [2:13], and the second, in the mention of Shahzoda Ansariy by Navoi, notes that her mother was Bediliy [2:75] and on Biche (Bibicha) Munajjima [2:90 ], among other things, he proves in the chapter of Hoja Alouddin as she was his sister.

Bediliy is a contemporary of Alisher Navoi, whose name first appears in the Navoi's memoir, but not as a poetess, as noted above, but as the mother of a poet named Shahzoda Ansari, the son of Sheikh Abdullah Devona. "It seems that his mother is also women of high virtues and calls herself as Bediliy. And this verse belongs to her:

Ravam ba bog'u zi Nargis du dida vom kunam

Ki to nazaram on sarvi xushixorot kunam.”

As for Mehriy, Hakim described her as Tabibi's wife and a bad-tempered woman. Mehriy is one of the most famous poetesses of the time of Hirotiy and Bediliy, and Alisher Navoi was the first to write a description of these poetesses in the golden pages of history. However, as time went on and worldviews changed, the translators of the "Majolis un-nafois" took a different approach to the issue, trying to rectify this shortcoming of the memoir as much as possible and adding information about women poetesses in their translations. The first Persian translation of "Majolis un-nafois", in Fakhri Hiraviy's "Latoyifnoma", included the ninth session, including the mention of Ofaq Begim Jaloir.

\section{Main part.}

Muhammad Muzaffar Hussein's memoir "Ruzi Ravshan" (رو شن روز) was written in 1879, size $24 \times 16$, and stored at the Institute of Oriental Studies of the Uzbekistan Academy of Sciences under the number №3700 inv. The work contains 868 verses.

Muzaffar Hussein was brought up well in a famous family. He had no match in the calligraphy and was a profound scholar of Persian poetry.

Muzaffar Hussein's memoir "Ruzi ravshan" was created under the influence of "Sham'i anjuman",
"Negariston", "Subhi Gulshan". The poet was 17 years old when he wrote memoir "Ruze Ravshan". In the memoir, the poet gave information about 2411 Persian-speaking Indians, Persians, Turkestanians, Afghans and Tajiks who lived before and at his time. In the memoir, the names are arranged in alphabetical order, each chapter consisting of special letters, beginning with Obi Termezi and ending with Yunas Abkhari. Muzaffar Hussein begins his memoir by saying that he decided to create this memoir to include the names of poets who were not present in the memoirs of "Sham'e Anjuman", "Subhi Gulshan", and "Negaristan" [4:12]. He singled out the letters "shin (ش)", "sod (ص)" and "nun(ن)" as symbols of memoirs. Due to the lack of information about the Persian-speaking Indians in these three memoirs, Muhammad Husayn enriched his memoir with the Indians. The Tazkira was first written in Nasta'liq script on kukhi paper and printed in lithography in Buhapol, and later a copy from the first edition was taken and published in Tehran [3: 640-644]. Since this memoir came in alphabetical order, the memory of 35 women came among the memory of men. 4 women in "Alif", 1 woman in "Pe", 3 women in "Be", 3 women in "Jim", 5 women in "He", 1 woman in "Dol", 2 women in "Re and Ze", "Sin" 1, "Shin" 1, "Sod" 1, "Ayn" 3, "Fe" 2, "Kof" 1, "Mim" 3 and "Nun" 2 women were mentioned respectively. These women are of Indian, Turkmen, Tajik, Afghan, and Persian origins. It is also mentioned not only by the poetesses but also by the woman who was acquainted with the poetry, but who was a perverted woman or a dancer like Shahi. Bediliy Hiyabaniy (in the sense of a street) was a prostitute, from whom:

That is: The full-blooded eye and the raw imagination are in this babe, a fiery furnace filled with fire, and a bunch of conspiracy is in her [4: 132].

The name Bediliy is also mentioned in the memoir of Akhtartabon [1:8], but it is not found in other memoirs. 


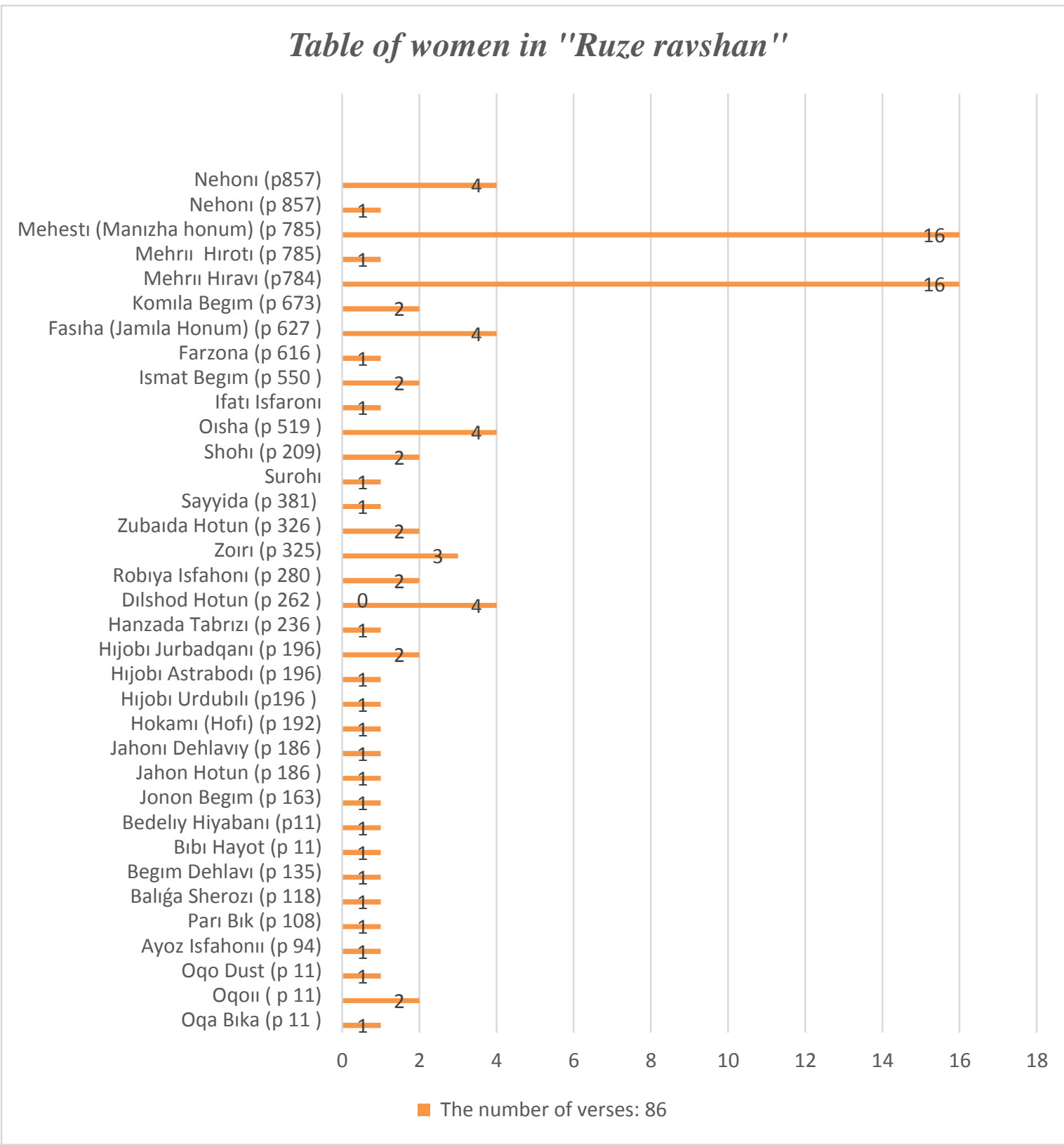




\section{EPRA International Journal of Research and Development (IJRD)

The above table is based on the lithograph stored at the Institute of Oriental Studies named after Abu Rayhan Beruni of Uzbekistan Academy of Sciences under inventory number №3700. The table shows that the memoir "Ruze Ravshan" contains the names of 35 women and the number of verses of their poems is 86 .

Muhammad Husayn also used the first memoir dedicated to women, "Javahir ul-ajoyib". We compare the data on women mentioned in both memoirs.

$$
\begin{aligned}
& \text { هركه كفر زلف او بيند زايمان بكنرد. }
\end{aligned}
$$

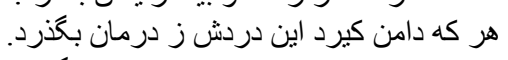

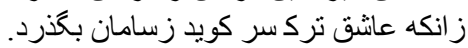

$$
\begin{aligned}
& \text { كرية زارش جو بيند يار كريان بكذرد }
\end{aligned}
$$

Fatima Hotun Dustiy - Musamateyi Fatima Hotun Darveshzoda is the daughter of Pir Darvesh Qiyom Sabzevori. She was a very cheerful and good poet reader. Her pen-name was Dustiy. This ghazal is hers [5: 129]: In "Ruze Ravshan" it is written that she was the daughter of Oqo Dust Darvesh Qiyom Sabzevori and only the first verse of the following ghazal is quoted [4:11]. This ghazal is quoted in with more detail in "Javahir ul-ajoyib":

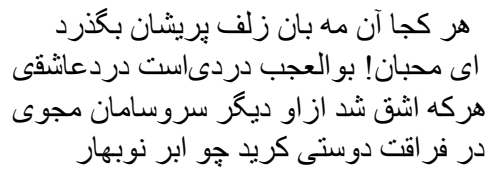

\section{Prose translation of verses:}

Wherever this absent minded goes,

Whoever sees his blasphemy let him believe.

O Mahbon! It's a wonderful pain, the pain of love,

Whoever embraces this pain let him leave the medicine.

Do not seek wealth and riches from anyone who is in love,

Because the lover loses his head, loses his wealth.

In your flame, Dustiy is burnt like a cloud of early spring,

Let the mourners weep bitterly as friends are in vision.

The verses of the ghazal describe the difficulty of the pain of love, the motif of the loss of consciousness of every person in love. In this ghazal, mystical meanings are expressed through the words mind, blasphemy, to believe, and mahban. The verses undoubtedly have a mystical meaning. It does not mean to leave religion out of faith and replace religion with disbelief, but rather a hidden meaning is expressed. True Love and admiration is the love of God, and it is a sign that a person who enters this path will renounce all worldly desires.

The name of Fatima Hotun Dusti is given in "Tazkirat ul-Khawatin", and the name is gives as Dustiy in "Tazkirat ul-neso", the name is given as Ogo Dust in "Akhtartabon" and "Pardaneshinone suhanguy", and her name is given as Mussamateye

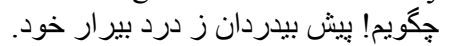

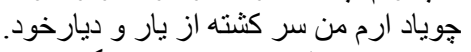

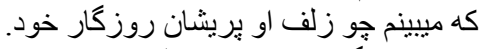

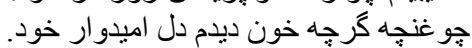

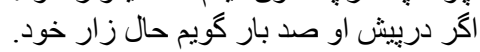

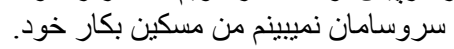

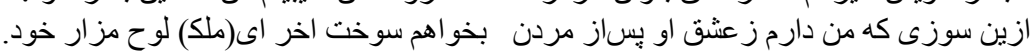

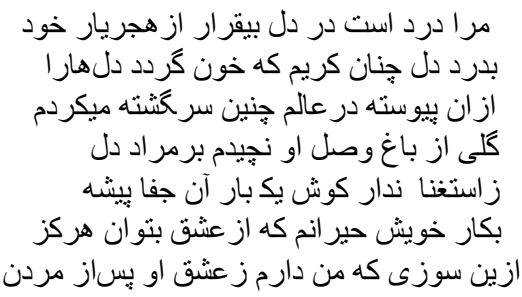

Ogana Dust (Ogo Dust) in "Mirot ul-hayol" and the poem in the memoir "Javohir ul-ajoyib" is given exactly.

Shokh Malak Sayyid Begim. Sayyid Begim, described as humble and pious, is the daughter of Sayyid Hassan Korkiyon, who was famous in Astrabad and was considered one of the most powerful nobles of the Jorjan region. Her real name is Shah Malak, and her style of poetry is very gentle and delicate. She got the pen-name Malak because her name was Malak, and at that time she herself was from the category of Royals. Here in this land the poetess is described as poetess Begim, I have seen a really good work by her. She might have written this ghazal about herself [5: 126]:

Prose translation of verses:

I have instability and pain in my heart,

What about my unstable pain in the face of awakening?

If friends and land are reminded of,

The noble heart bleeds in pain.

The world is as connected to him as kibbutz,

I see his ringlet in my desolation.

I did not pick flowers from the garden to see him,

Because in the bud, I saw blood like a hopeful heart. 


\section{EPRA International Journal of Research and Development (IJRD)

Even if I informed of myself before him,

I have never been pleased of that sufferer.

I am always amazed at the work of love,

I can't find a place to hide from poverty and idleness.

Even after death, I burn in his love,

O Malak, I also want to burn even in my grave.

In this ghazal, the groans of the heart and the anguish of the heart are sung. Lyrical experiences are described in verses with both philosophical and literary meanings. The lover sings from the pain of the martyr that she cannot find a place to go, even if she enters the grave. In Maqta, the torment of romantic separation is equated with the torment of the grave. The image of the lover's anguished state of separation intensifies as it goes from verse to verse in the ghazal, reaches its climax, and even ends with a scene that leads to death. In describing the emotional state of the lover in the ghazal, the poet makes appropriate use of such artistic arts as husni talil (beautiful proof) (3,4 verses), tashbeh (immitation), tashhis (animation) (6 verse), and exaggeration $(6,7$ verses).
In "Ruzi Ravshan", Saida's pen-name is Saidabegim Jurjani, the daughter of Said Nasir Jurjani, and the first verse of the above ghazal is quoted [4: 381]; In "Akhtartabon" seven verses of the above ghazal are given; In the memoir "Pardaneshinone Suhanguy", Shah Malak's name is Saida Begim Alaviya, and in the "Tazkirat ul-Nesa", which contains all seven verses of the above ghazal and two ghazals of seven more verses, the ghazal in the "Javahir ul-ajoyib" is mentioned under the name of Malika.

Hijabiy is the daughter of the bright Kubak in generosity, that is, the daughter of Mavlana Badriddin Hilaliy, who did not need to be defined. The subtlety of Hijabiy can also be felt through her poetry. It has been said that this rhyme is her ghazal [5: 128]:

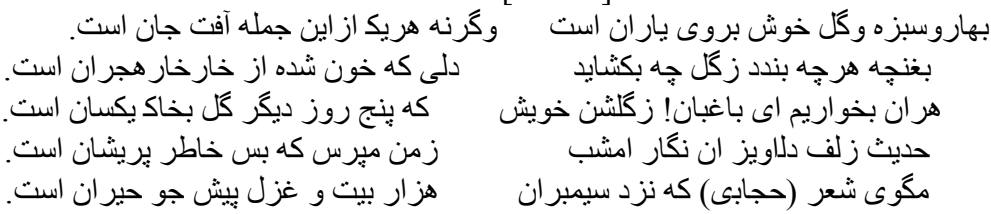

Prose translation of verses:

Spring, blossom, flowers, is the beauty of the friends,

And each of these words is soul pleasing.

If everything loads into a bud, what opens from a flower,

The heart full of blood is in pain from thorns.

O gardener! Every moment we enjoy the spring,

Five days later the flower is uprooted in the soil.

Tonight he saw darling's hesitant look through hair,

Don't ask me, my memory is broken.

Do not recite, Hijabiy, poetry in the presence of charms,

A thousand verses of ghazals are amazed before them.

In this poem, the image of spring and the poet's philosophical observation of life are expressed through a beautiful metaphor. Allah can be known through the beauties $\mathrm{He}$ has created. Spring, no matter how beautiful the flowers are, is temporary and ultimately the final destination of them is pointed to be the soil. For the flower-nature is a symbol of the creature by Allah, and the hair has several meanings that cover the face in mysticism. In the fourth verse and maqta', Hijabiy tried to describe her state in the hereafter. The formation and appropriate use of words by the poet introduced the art of tanosub (use of hyponyms) through the words spring, flower, gardener, thorn, bud, soil, which ensured the logical integrity of the ghazal.
In the memoir of "Ruze Ravshan", the name of Hijabiy is given as Hijabiy the daughter of Astrabadiy Hilaliy, and 3 verses of the above ghazal are given.

In the memoir "Pardaneshinone suhanguy" it is written that Haji Hodi Astrabodiy's daughter has no match in beauty, the sun that illuminates the world, is hidden from the jealousy of her, and the moon of the world is curbed before her beauty. The poetess did not remove the hijab from her face because she was too pious, and for this reason she took the pen-name Hijabiy, the following verse is about her:

Your beauty and the sun are both one,

Both your pain and your challenge are the

same. 


\section{EPRA International Journal of Research and Development (IJRD)

In "Akhtartabon", she is said to be the daughter of Mullo Hilaliy.

The memoir of "Mirat ul-Khayyal" contains the same information as in "Pardaneshinone suhanguy".

\section{CONCLUSION}

The three poetesses whose names are mentioned in the memoirs, Fatima Hotun Dustiy, Shah Malak Sayyid Begim, and Hijabiy, all have motifs of divine love, pain and separation. But this motif is embodied in each poet's own poetic style. They all have a feminine charm.

In "Javohir ul-ajoyib", Fakhri Hiraviy not only preserved the names of women poets, information about them, but also their place in the art of poetry, citing examples from their poetic works. For this reason, the memoir of "Javohir ul-ajoyib" became famous during Fakhri's lifetime and paved the way for later memoir writers. It is for this reason that the names of many women poetesses have survived to our time. In particular, Muhammad Muzaffar Hussain also used Fakhri's method in describing women, giving verses, and increasing their number in accordance with his time.

Since Muhammad Muzaffar Husayn wrote the memoir "Ruze Ravshan" under the influence of the father and sons' works "Subhe Gulshan", "Sha'me Anjuman" and "Negaristone Sukhan", we can see that in addition to the women in these three tazkirs, he also included several other women. In particular, we can see the names of 21 women in "Subhe Gulshan", 16 women's commentaries in "Sham'e Anjuman" and 7 women's names in "Negaristone Sukhan". Muhammad Muzaffar Hussain, taking a special approach to the commentaries of Mehriy Hiraviy and Mehestiy (Manija Khanum), used the memoirs that survived up to his time and quoted their 16-verse poems. This serves to continue the information about Mehriy and Mehestiy, even though they lived centuries before the author.

As Muhammad Muzaffar Hussain enumerated the names of women in the work and tried to interpret them beautifully and to preserve the recognition of these women with respect throughout the course of history, in addition, the poetic passages from the women's commentary are invaluable in the study of the history of literature, the history of literary relations.

\section{REFERENCES}

1. Abdul Kasım Muhtasham Shervonı Bahrpolı. Akhtartabon. P.8. http//dli.iiit.ac.in

2. All-Shir Nava`. Majolis un-Nafois. www.ziyouz.com.kutubxonasi. P.13. P.75 P.75. P.90

3. Ahmad Gulchın Maa ni. Tarik-e tadkeraha-ye farsi. 1-V.Tehron.-1348.P. 640-644.
4. Muhammad Muzaffar Husein. Ruze ravshan. №3700. P-11. P-12. P-132. P-381.

5. Said Hisomiddin Roshidiy publishing. "Ravzat us-salotin" and "Javohir ul-ajoyib". Khaydarobod: "Vafoiy", 1968. P.126, P.128, P.129.

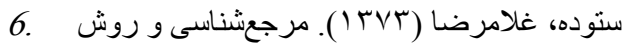

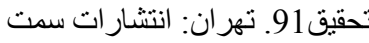

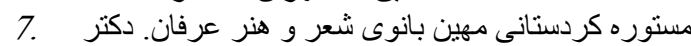

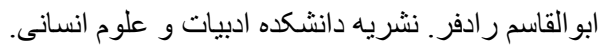

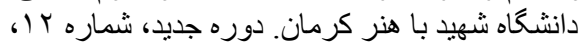
1) زمستان

8. http://www.perslit.com/rabeh.parvin.htm

9. https://cafenabat.com. 